(RESEARCH ARTICLE)

\title{
Investigation of basic biological properties of the specific Pyocyaneus bacteriophage
}

\author{
Davitashvili Magda David *, Zuroshvili Lamara David, Margalitashvili Darejan Aleksandre and Azikuri Gela \\ Shota
}

Iakob Gogebashvili Telavi State University, 1, Kartuli Universiteti str., Telavi, 2200, Georgia.

Publication history: Received on 30 March 2020; revised on 05 April 2020; accepted on 07 April 2020

Article DOI: https://doi.org/10.30574/wjarr.2020.6.1.0085

\begin{abstract}
Biological properties of the specific Pyocyaneus bacteriophage obtained in our laboratory from the sewage waters comply with all the requirements for the diagnostic bacteriophages. The MT-2 bacteriophage is characterized with strict specificity and wide range of action. The phage has high absorption ability, abundant yield and short latency. It is highly thermostable as well. It was found that the MT-2 phage could be used, along with application of the phage-sensitivity test, for identification of the newly-isolated Pseudomonas aeruginosa strains. The phage identification method has a special importance because of its time-saving property. It is known that the bacteriological examination requires three days, while the application of the diagnostic bacteriophages significantly shortens the term - 28-30 hours were found to be sufficient.
\end{abstract}

Keywords: Bacteriophage; Biological properties; Pyocyanic bacteria; Sewage waters; Diagnostics

\section{Introduction}

In recent years many countries have noticed increase of specific gravity of infections, which are due to the Gram-positive bacteria - specifically to the Bacillus pyocyaneus. The infections induced by these bacteria, along with the staphylococcal infections, have a leading position in the in-hospital diseases as well. If in the 60-s and 70-s there were few single cases of hospital infections, in the 80 -s and 90 -s the number of outbursts increased to the threatening values $[1,2,3]$.

The hospital pyocyanic infections most frequently are conserved in surgical departments, urologic clinics, and burn centers. These infections are characterized with heavy course and often are the cause of the lethal outcome. The pyocyanic infections may be the primary source of a diseases $[4,5,6]$.

The majority of Bacillus pyocyaneus strains possess a marked natural resistance towards the number of known antibiotics, which property of course hinders treatment and decreases its efficiency.

The wide spread of infections elicited by Pseudomonas aeruginosa and resistance of Bacillus pyocyaneus towards the most of antibacterial drugs promoted investigation and elaboration of the specific bacteriophages with an aim to cure pyocyanosis. On the other hand the efficiency of treatment of the pyocyanic patients considerably depends on the timely diagnosis of infectious pathogenic organism $[7,8,9,10]$.

Isolation and investigation of the new species-specific bacteriophages with standard properties may play a considerable role in an improvement of the quality and in speeding up of the bacteriological diagnostics. This may also help to decipher the etiology of infectious processes and to evaluate environment pollution due to the pathogenic microorganisms. Furthermore, enrichment of the diagnostical phages' collection has a theoretical value as well because it allows to establish general regularities, which lay in the basis of bacteriophages' taxonomy $[11,12]$. However all the isolated bacteriophages could not be used with diagnostic purposes. The indicator value have only virulent

\footnotetext{
* Corresponding author: Davitashvili Magda David E-mail address: magda.davitashvili@tesau.edu.ge
} 
bacteriophages, which are characterized with the following properties: definitive, strictly limited and stable range of action, marked absorption ability, short latency, high index of effective plurality, and thermostability.

All the known P. aeruginosa bacteriophages, according to their biological properties, cannot be used as an indicator bacteriophages.

The aim of the present investigation was selection and study of the main biological properties of the new specific pyocyanic bacteriophage, and establishing the possibility of its application in identification of the newly-separated $P$. aeruginosa.

\section{Material and methods}

The following materials were used in the experiments: The phage MT-2; Bacteria - total of 1230 strains of the Enterobacteriaceae family; 430 - P. aeruginosa, 5 - P. fluorescens, 5 - P. maltophilia, 5 - P. testosterone, 5 - P. putida, 5 P. stutzeri, 197 - Shigella, 224 - Salmonella, 199 - E. coli of various serotypes, 61 - Proteus, 94 - J. enterocolitica.

General methods of the work with phages were adopted from the Adams' book. The study of bacterial strains and phages was done with the following methods traditional bacteriological methods $[13,14,15]$.

\section{Results and discussion}

At the beginning of the experiments the P. aeruginosa strains were investigated with an aim to find out presence of the moderate phage, release of which from the cultures during the joint cultivation of the strains could lead to the erroneous results.

The bacteriophages against $P$. aeruginosa were separated from the sewage waters. Total of 25 clones of $P$. aeruginosa bacteriophages were separated, out of which, according to the general taxonomic signs (morphology, serologic properties, lythic spectrum), 13 clones were selected corresponding to the III ( 9 clones) and V (4 clones) morphological groups, which met the requirements for the diagnostic phages.

The MT-2 phage constitutes a mixture of the specific P. aeruginosa bacteriophages' clones. Selection of the specific pyocyanic bacteriophages was carried out by the genetically uniform bacteriophages' isolation method from the separate negative colonies.

According to the morphology of sterile blots the MT-2 phage is polymorphous. The diameter of negative colonies is 1-5 $\mathrm{mm}$. As a result of investigation of MT-2-phage-cell interaction (standard culture of P. aeruginosa 1038) it was established that the bacteriophage has a high absorption ability (maximum time of absorption -10 min), productivity (110 particles per one infested cell), and short latency.

The pyocyanic bacteriophage was characterized with quite a high thermal stability. The total inactivation of the phage occurred at $85^{\circ} \mathrm{C}$, following the $30 \mathrm{~min}$ heating. The least threshold for inactivation was $55^{\circ} \mathrm{C}$ (Table 1).

Table 1 Biological properties of the specific MT-2 pyocyanic bacteriophage

\begin{tabular}{|c|c|c|c|c|c|c|}
\hline \multirow{2}{*}{$\begin{array}{l}\text { Morphology of } \\
\text { the negative } \\
\text { colony }\end{array}$} & \multirow{2}{*}{$\begin{array}{l}\text { Number of } \\
\text { particles per } \\
1 \mathrm{ml}\end{array}$} & \multirow{2}{*}{$\begin{array}{l}\text { Maximum } \\
\text { adsorption, } \\
\text { min }\end{array}$} & \multirow[t]{2}{*}{$\begin{array}{l}\text { Latency, } \\
\text { min }\end{array}$} & \multirow[t]{2}{*}{ Productivity } & \multicolumn{2}{|c|}{$\begin{array}{l}\text { Thermal inactivation after } \\
\mathbf{3 0} \mathrm{min} \text {, threshold }\end{array}$} \\
\hline & & & & & Least & Top \\
\hline $\begin{array}{l}\text { Polymorphous } \\
\mathrm{d}=1-5 \mathrm{~mm}\end{array}$ & $2 \cdot 109$ & 10 & $60-65$ & $100-110$ & $55^{\circ} \mathrm{C}$ & $85^{\circ} \mathrm{C}$ \\
\hline
\end{tabular}

Specificity of the MT-2 phage was investigated in the cross-lysis experiments with the heterologous species of microorganisms - Escherichia, Shigella, Salmonella, Proteus, Jersinia enterocolitica. 
The range of lytic activity of the MT-2 bacteriophage was evaluated in the collection of museum cultures - $P$. aeruginosa - 25, P. fluorescens - 5, P. maltophilia - 5, P. testosterone - 5, P. putida - 5, P. stutzeri - 5. Besides, experiments were carried out in 1575 newly-separated strains of various species and serologic types of the Enterobacteriaceae family.

Obtained material allows to suggest that the MT-2 bacteriophage has a strict specificity and wide range of action towards the newly-isolated strains of P. aeruginosa (rate of lysis -93.4\%) (Table 2).

Table 2 Spectrum of the lytic activity of the MT-2 pyocyanic bacteriophage

\begin{tabular}{lllll}
\hline № & $\begin{array}{l}\text { Strains of the } \\
\text { Enterobacteriaceae family }\end{array}$ & $\begin{array}{l}\text { Number of } \\
\text { strains }\end{array}$ & $\begin{array}{l}\text { Number of lysated } \\
\text { strains }\end{array}$ & \% \\
\hline 1 & P. aeruginosa & 430 & 425 & 93,4 \\
2 & P. fluorescens & 5 & - & - \\
3 & P. maltophilia & 5 & - & - \\
4 & P. testosterone & 5 & - & - \\
5 & P.putida & 5 & - & - \\
6 & P. stutzeri & 5 & - & - \\
7 & Sh. sonnei & 74 & - & - \\
8 & Sh. disenteria & 67 & - & - \\
9 & Sh. flexneri & 59 & - & - \\
10 & Salmonella typhi & 127 & - & - \\
11 & Salmonella paratyphi & 97 & - \\
12 & E. coli various serotypes & 201 & - \\
13 & Proteus & 59 & 95 &
\end{tabular}

However, for evaluation of the phage applicability in phage-identification an essential condition is, besides its specificity, the stability of this particular property. To elucidate latter condition the MT-2 phage, which is characterized with very high species-specificity, was investigated according to the V. V. Avrekh method (1955) and was found to possess a high stability of the specificity of its action as well. Following the many-fold passing on homologous and heterologous strains, their mixtures, and on the stable clones of the homologous bacteria, the MT-2 phage remained specific and lysated only single species of $P$. aeruginosa. Thus, the absence of reproducibility on the heterologous strains shows the high stability of specificity of the phage.

\section{Conclusion}

The biological properties of the pyocyanic bacteriophage MT-2 conforms to the requirements for the indicator phages. It possesses selective activity, high adsorption property along with short latency, sufficient productivity, and thermalstability. The specific pyocyanic bacteriophage could be utilized for the preliminary identification of newlyisolated $P$. aeruginosa, using the phage-sensibility test.

The specific pyocyanic bacteriophage considerably decreases the volume of required bacteriological examinations. While the routine bacteriological examination requires at least 3 days, with an aid of our phage the time for identification of the pyocyanosis pathogenic agent is reduced to 28-30 hours, starting from the material inoculation. 


\section{Compliance with ethical standards}

\section{Acknowledgments}

I am grateful to the Rector and Administrator, Iakob Gogebashvili Telavi State University, to the Department of Natural Sciences for their support.

\section{Disclosure of conflict of interest}

There is no conflict of interest amongst the authors.

\section{References}

[1] Kasper DL and Fauci AS. (2010). Harrison's Infectious Diseases. McGraw-Hill.

[2] Mandell, Douglas and Bennett's. (2017). Infectious Disease Essentials. Elsevier.

[3] Totten PA, Lara JC and Lory S. (1990). The rpoN gene product of Pseudomonas aeruginosa is required for expression of diverse genes, including the flagellin gene. Journal of Bacteriology, 172 (1), 389-396.

[4] Davis BD, Dulbecco R, Eisen HN and Ginsberg HS. (1990). Fourth edition. Microbiology, 555.

[5] Actor JK. (2012). Second Edition. Immunology and Microbiology. Elsevier.

[6] Johnson AG, Ziegler RJ and Hawley L. (2010). Fifth edition. Microbiology and Immunology. Lippincott Williams \& Wilkins.

[7] Kurtboke I. (2012). Bacteriophages. In Tech, Croatia.

[8] Buxton BA, Jensen LA and Gregg R. K. (2010). Lippincott's Illustrated Review of Microbiology \& Immunology. First Edition. Lippincott Williams \& Wilkins, Wolters Kluwer.

[9] Hogg S. (2013). Essential Microbiology. Second edition. John Wiley \& Sons Ltd, England.

[10] Roncero C, Darzins A and Casadaban MJ.(1990).Pseudomonas aeruginosa transposable bacteriophages D3112 and B3 require pili and surface growth for adsorption. Journal of Bacteriology, 1899-1904.

[11] Carlson K. (2005). Appendix: Working with Bacteriophages: Common Techniques and Methodological Approaches. In Bacteriophages: Biology and Applications (E. Kutter and A. Sulakvelidze, eds.) 437-487.

[12] Tammela T, Konffuri M and Usenius R. (1990). Journal Hospital Infection. 15. (Suppl. A), 69-76.

[13] Adams MH. (1959). Bacteriophages. New York Interscience Publishers, New York.

[14] Ackermann HW. (2005). Bacteriophage classification. In Bacteriophages: Biology and Applications (E. Kutter and A. Sulakvelidze, eds.), 67-90, 88-490.

[15] Toth EM, Borsodi AK, Felfoldi T, Vajna B, Sipos R and Marialigeti K. (2013). Practical Microbiology. Eotvos Lorand University.

\section{How to cite this article}

Davitashvili MD, Zuroshvili LD, Margalitashvili DA and Azikuri GSh. (2020). Investigation of basic biological properties of the specific Pyocyaneus bacteriophage. World Journal of Advanced Research and Reviews, 6(1), 73-76. 